\title{
Classical humanitarianism and resilience humanitarianism: making sense of two brands of humanitarian action
}

\author{
Dorothea Hilhorst
}

\begin{abstract}
Humanitarian aid has long been dominated by a classical, Dunantist paradigm that was based on the ethics of the humanitarian principles and centred on international humanitarian United Nations agencies and non-governmental organizations. While in previous decades alternative paradigms and humanitarianisms evolved, this classical paradigm remained the central narrative of humanitarianism. In recent years, however, this paradigm has been paralleled by a resilience paradigm that is focused on local people and institutions as the first responders to crises. Whereas classical humanitarianism is rooted in the notion of exceptionalism, resilience humanitarianism starts from the idea of crisis as the new normality. This paper discusses the two paradigms and the incongruent images they evoke about crises, local institutions and the recipients of aid. The article puts forward the case for studying the ways in which these contrasting aid paradigms shape practices, dealing with the importance of discourse, the social life of policy, the multiplicity of interests, the power relations and the crucial importance of understanding the lifeworld and agency of aid workers and crisis-affected communities. The article demonstrates how the stories that humanitarians tell about themselves are based on highly selective views of reality and do not include the role they themselves play in the reordering and representation of realities in humanitarian crises.
\end{abstract}

Humanitarian aid has long been dominated by a paradigm that was rooted in exceptionalism, grounded in the ethics of the humanitarian principles and centred on international humanitarian United Nations (UN) agencies and non-governmental organizations (NGOs). In recent years this 'classical Dunantist paradigm' has been paralleled and partly overtaken by a radically different paradigm, which can be called the 'resilience paradigm'. Whereas the classical paradigm centres on principled aid, the resilience paradigm foregrounds building on local response capabilities. Both paradigms have a strong logic that dictates a specific way of seeing the nature of crisis, the humanitarian system, the scope of the humanitarian response, the identity of humanitarian actors and the nature of institutions and people in crisis-affected areas. They result in different bodies of practice, which can be labelled 'classical humanitarianism' and 'resilience humanitarianism'. This article will unravel the two aid paradigms. Although they are often

Correspondence: hilhorst@iss.nl

International Institute of Social Studies, Erasmus University, Kortenaerkade 12, 2518 AX Den Haag, The Netherlands

Springer Open

(c) The Author(s). 2018 Open Access This article is distributed under the terms of the Creative Commons Attribution 4.0 International License (http://creativecommons.org/licenses/by/4.0/), which permits unrestricted use, distribution, and reproduction in any medium, provided you give appropriate credit to the original author(s) and the source, provide a link to the Creative Commons license, and indicate if changes were made. loosely used and intermingled in practice, the article maintains that many issues and dilemmas in humanitarian action today are related to inconsistencies in the different approaches that humanitarian aid has adopted.

The dominance of the classical Dunantist paradigm has been challenged in previous decades. In the 1990s, when it was realised that many crises were protracted in nature and when large development agencies started to engage in humanitarian crises, the adage of linking relief to rehabilitation to development (LRRD) was, for example, gaining importance. This trend, as other trends calling for a different practice of aid such as rights-based approaches, was, however, backgrounded after the start of the War on Terror in 2001 when much aid started refocusing on its life-saving core. Moreover, LRRD was usually understood as a sequential approach to aid, where humanitarian aid aimed to be better aligned with early recovery and development. Voices to completely redesign relief aid to seek building on people's and communities' capacities and institutions (Richards 1996) were rare and mainly institutionalized in development agencies that always had worked with

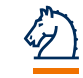


local partners. There have also been analyses of the 'real' politics of humanitarianism with all its variations (Stoddard 2003), and some of the aspects of what I refer to in this article as 'resilience humanitarianism' have been referred to previously as 'New humanitarianism,' 'where humanitarian assistance became more aligned with Western liberal peace agendas' (Gordon and Donini 2015:87). Although new humanitarianism mainly referred to the politics of allocation of aid, and less so on its delivery, critiques of humanitarianism and different humanitarian politics have thus a long history, and previous trends partly led up to the changes this article refers to as resilience humanitarianism.

The article analyses the two paradigms and discusses how aid-informed by one of these paradigms or a mix of them-is shaped in practice. The discussion of the two paradigms is based on long-term ethnographic study of aid-society relations (aidnography for short). Practiced social scientists will recognize how it builds on Durkheim, Douglas, symbolic interactionism, Foucault and Giddens, among others. It provides a framework that derives from and underpins a steady stream of ethnographic studies into humanitarian aid (Harrell-Bond 1986; Apthorpe 2005; Auteserre 2014; Marriage 2006a and many others). In these studies, aid provision is seen as an arena, where aid is shaped through social negotiation of actors in and around the aid chain (Hilhorst and Jansen 2010; Hilhorst and Serrano 2010).

The 'arena perspective' focuses on the everyday practices of policy and implementation and highlights how different actors develop their own understanding and strategies around shared vocabularies, ambitions and realities of aid, and how this leads to frictions and contradictions in aid delivery. In the last decade, we have used the arena perspective to analyse a large number of case studies on humanitarian praxis in different settings and types of crises, ranging from the everyday politics of disaster risk reduction and climate change adaptation in Mozambique (Artur 2011; Artur and Hilhorst 2012), of aid and institutions in Angola (Serrano 2012), of peacebuilding (van Leeuwen 2009), of community-driven reconstruction (Kyamusugulwa 2014; Kyamusugulwa and Hilhorst 2015) and of humanitarian governance in Kakuma refugee camp (Jansen 2011).

Practices of aid are to some extent dictated by the needs and conditions imposed by the humanitarian crisis. However, as aidnographies consistently found, practices of aid are also shaped by the mandates of agencies, the way they give meaning to their work and the assumptions they have about the local context and the population they serve. This article, then, analyses the stories that aid tells about itself, namely the two paradigms of classic Dunantist humanitarian aid and the turn to resilience, and the assumptions that (implicitly or explicitly) underpin these stories.

\section{Paradigms}

Paradigms stand for a particular way of understanding crisis. Before discussing the two paradigms underpinning classical and resilience humanitarianism, this section provides a number of (cautious) notes about the working of paradigms.

Despite their appearance, crises are not self-evident. There are always multiple ways in which crises can be understood and acted upon. This means that humanitarian crises attain their specific realities through the language and practices in which actors negotiate the meaning of crisis (Is it exceptional? What are its causes? Is there someone to blame?), communicate about this and develop and implement responses. Our field of interest is full of stories: moral principles, political one-liners, policies and dramatic media representations. Understanding the working of discourses of crisis and crisis response is important in analysing how people and institutions deal with humanitarian crises. A classic example concerns socio-natural disasters, whereby it makes a huge difference for the response if crisis is understood as an act of God; as the outcome of natural phenomena or climate change; or as the combined effect of hazard, vulnerability and political incapacity (Blaikie et al. 1994; Hilhorst 2004).

Paradigms are a way of thinking that informs policy and practice, but they do not dictate practice and are subject to interpretation. Policies and principles are formulated, understood and altered in the everyday practice of humanitarian action on the ground. Humanitarian principles, for example, are interpreted differently by different actors and are more contextual than universal (Leader 2002; Minear 1999). They only become real through the way in which service providers interpret and use them (Hilhorst and Schmiemann 2002). Policies for peacekeeping, disaster risk reduction, relief and reconstruction are likewise negotiated and result from the interaction between different stakeholders, who try to make policy fit their own perspectives of the problem and goals. As Colebatch (2002) pointed out, a critical policy analysis means that we cannot even take it for granted that policies are meant to be implemented. International policies are quite often ritualized attempts to appease audiences at home rather than to effect a change in practice. When we view policies as processes (Mosse 2005) or emergent properties, it is important to invest in their 'social life': their history, genesis, meaning and 'real' objectives. An outstanding example concerns anti-terrorist policies that have come to be a dominant factor in the shaping of aid. Notwithstanding their original intentions, these policies are easily instrumentalized by national political actors who want to neutralize their opponents, and have the effect that certain actors are excluded and certain populations in distress are discriminated against or cannot be reached. The effects are further complicated by the reactions of local communities and their perceptions that such 
legislation may be anti-Islam, rather than anti-terrorist (Macdonald 2017; Maxwell and Majid 2016).

Similarly, paradigms, policies and other ordering principles are never singular in driving practice. This can be exemplified by a note about interests. In my perspective, actors are always (self)-interested, but interests are rarely singular and consistent. Take the case of INGOs. A lot has been written about the instrumentalization of aid (Donini 2012), whereby aid is seen as the playball of politics. In this view, humanitarian action has little to do with its principles but is instrumentalized by competing and interested actors, including donors, national governments and rebel movements. In the case of INGOs, it has been suggested that the competition among these agencies leads to a tendency to go for the money and favour projects that are likely to raise funds (Bob 2005). There is abundant evidence, and many NGO workers will know from experience, that this is true in many ways.

However, the need to raise funds is not the only driver of NGOs, and NGO decision-making is in fact a highly complex process. In all these years that I have studied NGOs and talked to their staff, I have been struck by the fact that people and organizations are usually genuinely and altruistically committed to their values and the core principle of humanity, i.e. 'the desire to prevent and alleviate human suffering wherever it may be found ... to protect life and health and to ensure respect for the human being'. ${ }^{1}$ However, the principle of humanity is not the only driver of an agency or its people. NGOs are simultaneously driven by the desire to maintain their operations. This is a legitimate desire, as it would be extremely complicated and unethical for organizations to hire and fire staff according to whichever crisis comes by. It only becomes problematic when the desire to maintain operations overrides the desire to save lives and restore dignity. Such an imbalance between altruistic and selfish interests becomes especially visible in cases where aid becomes 'hyped' such as during the Asian tsunami of 2004 when an abundance of resources created a visible competition among aid agencies concerning who should benefit (Hyndman 2012; Fernando and Hilhorst 2006; Hilhorst and Douma 2018). Studying aid from an arena perspective means keeping an open mind about the multiple interests and drivers of aid and how these work out in everyday practice.

While paradigms can be seen as a way in which powerful actors impose their understanding of reality, this does not mean that aid comes about in a top-down manner alone. There are obvious actors-and humanitarian agencies are among them-that command powerful positions and who are largely able to define and give meaning to the crisis event, decide on policy and its effects and allocate resources (Olson 2000). Nonetheless, the power to achieve outcomes does not only rest with the 'usual suspects'. On close observation, power needs to be enacted to be effective, and this happens through social negotiation and by the interference of a large number of actors each of whom have a certain power to jointly shape the outcomes. This includes the recipients of aid, who in their strategies to obtain resources, for example through migration or through the manipulation of aid, may considerably reshape the landscape of humanitarian assistance. A recent example is how people from Syria and other conflict-affected areas massively decided to seek refuge in Europe in 2015 putting extreme pressure on the European Union in the process. Aid paradigms can be powerful, but practices of aid come about in more complex ways and by a multiplicity of actors.

\section{Classic Dunantist humanitarianism}

The dominant story that humanitarian aid has told about itself for decades is rooted in the experience of Henri Dunant at the Battlefield of Solferino in 1859. This set into motion the evolution of International Humanitarian Law and the definition and organization of modern humanitarianism as a principled endeavour. The first Geneva Conventions, initiated in the 1860 s, regulated the conduct of armed conflict and were seeking to limit its effect. They recognised the International Committee of the Red Cross as guardian of the conventions and ICRC - and the Red Cross Red Crescent movement in its wake developed to provide protection and assistance to war-affected. The classic paradigm of humanitarianism is based on the basic principles of humanity, impartiality, neutrality and independence, meant to ensure that humanitarian aid is purely needs-based: decisions to help must not be driven by political motives or by discrimination of any kind.

In the more than 150 years since the first Geneva Conventions and the foundation of the RCRC movement, humanitarian aid has become the occupation of a large range of diverse actors. Even though the extent to which these identify with the basic principles varies, the basic principles of humanitarian aid have found broad recognition and featured, amongst others, in the United Nations resolution 46/182 about the response to humanitarian crises in 1991; the NGO Code of Conduct of 1994 (in a watered down version); in the Good Humanitarian Donorship initiative, the preamble of the Core Humanitarian Standard; and, most recently, in the key documents of the World Humanitarian Summit in 2016.

Exceptionalism is at the heart of this classic paradigm, perhaps even more than the principles. A strict separation between crisis and normality is deeply engrained in legal and cultural norms worldwide. Humanitarian aid clearly belongs in the realm of crisis and exceptionality, serving as a temporary stop-gap for needs triggered by a specific crisis (Calhoun 2010). Exceptionalism is the major organizing principle of classic humanitarianism and is the 
backbone of many of the properties of aid including its short-cycle funding modalities and expensive operating procedures. As the system is organized for short-term, bounded operations, the definition of humanitarian crises follows the confines of the system, rather than the other way around. An intuitive definition of a humanitarian crisis is that the withdrawal of aid would lead to an immediate upsurge in mortality and morbidity. But what if this was turned around? Then a humanitarian crisis frame may also be applied to situations where delivery of cash relief would lead to an immediate reduction in mortality and morbidity. Would that not be the case in many areas where people live in slums or have unsafe access to drinking water? However, these types of crises are rarely framed as humanitarian. Definitions of humanitarian crisis are ring-fenced by being restricted to those situations (disasters triggered by natural hazards and conflicts) that the humanitarian machinery can hope to handle.

As alluded to in the introduction, humanitarian practice has always been varied, and many types of aid would divert from the ideal-typical relief-oriented and principled work of the ICRC or Médécins sans Frontières. There have always been many variations on the paradigm of aid, and there have always been contesting voices. Yet, the space paradigm has been very dominant in humanitarian discussions. Much of the critical literature about the politicization or competitiveness of aid has implicitly adhered to the ideal-typical notions of the humanitarian space, with criticism pointing out how aid deviated from its self-declared norms. Other realities also appeared in literature, but often in the form of a disclaimer. Critical literature on the 'empire' of humanitarian aid, for example, usually started by sketching a more varied picture, pointing to the importance of local responders, and then continued to focus on the core of international humanitarians of the Global North. The focus on international humanitarian aid also meant that the literature mainly focused on those periods and pockets of a crisis where this type of aid was to be found. A long-term research project on the history of aid in Angola revealed that such windows of international aid were brief during the three decades of conflicts (Hilhorst and Serrano 2010). For most of the long years of war, communities had to fend for themselves, with occasional support from churches or political actors such as Cuban doctors who came in the wake of Cuban military support.

The focus on international aid finds expression in the depiction of the humanitarian aid as a system whereby different parts are connected in a functional way. The organogram of this system has the UN Office for the Coordination of Humanitarian Affairs (OCHA) at the top and a second layer consisting of UN agencies, INGOs and the Red Cross/Red Crescent movement. A third layer might be added representing national-level aid providers, but it is also likely that these were left out of the picture. The foundation of the system consists of humanitarian principles, while the interagency standing committee (IASC) spurs a large number of policies and recipes for providing humanitarian aid. In the margin of the machine, quality mechanisms such as ALNAP, $^{2}$ Sphere, ${ }^{3}$ $\mathrm{HAP}^{4}$ and People in Aid (which have now been brought together in the Core Humanitarian Standard alliance ${ }^{5}$ ) are seen to oil the machine and do the necessary repair work.

The classic approach has a single focus on the importance of the humanitarian principles as a means of gaining secure access to people in need. It seems unaware of other trust-forgers that may enable access and work differently in different contexts, such as accountability and reliability or, in some cases, longstanding solidarity (Hilhorst 2005). In many areas, strict neutrality, isolation and the highly protective measures associated with fortified aid compounds (Duffield 2010) are necessary. In many other areas, good relations with partner organizations, displaying confidence in local staff, respectful behaviour and accountability pay off more in terms of security than do the humanitarian principles. The exclusive focus on principles also cements the identity of international actors as disembedded from society. DeChaine (2002: 363) observed that "By "humanitarianizing" space - representing it as a space for ethical and humane interaction - humanitarian agencies present themselves as actors void of the territorial or political context in which they operate'. A strong symbol of this image was the camp where people came for refuge, disconnected from their networks, livelihoods and societies and were completely dependent on the goodwill of international care.

National authorities and other local institutions are rendered invisible in classical humanitarianism. Where they enter into the analysis, they are treated with mistrust or with a preconceived idea that they require capacity building. In the 1990s, when humanitarianism became a centrepiece of the buffet of international relations and interventions, the full humanitarian international system was routinely deployed, even in cases of disasters triggered by natural hazards, where the sovereign government could and should have taken the lead. The Gujarat earthquake, when the Indian government took a stand against the invasion' by humanitarian agencies of their discretional space, was a turning point in which agencies had to reconsider their attitude (Harvey 2009). Nonetheless, when the Asian tsunami struck, a number of middle-income countries in 2004, officers of national NGOs who handled the first responses, felt ignored by international actors who had arrived much later at the scene. One person told me at the time: 'This UN official walked in and without even looking at our work, told us to move over because they had come to take the coordination'. 
A major engagement of the humanitarian international system with local institutions since the 1990s happened in the framework of capacity building. Capacity building is a terrible term that conveys a non-agentive infrastructure that gets built up by outside forces. Article 6 of the 1994 Code of Conduct for the Code of Conduct for the International Red Cross and Red Crescent Movement and NGOs in Disaster Relief declared, 'We shall attempt to build disaster response on local capacities'. The discourse of capacity building of local responders to crises continues to be pervasive and is an accepted discourse even in areas where the international humanitarians have been active for some decades (Hilhorst and van Leeuwen 2005). The discourse is problematic as it always seems to depict local responders for what they are missing, rather than recognizing their specific strengths, thus reinforcing existing power relations in the process. A recurring critique is that capacity building is geared to transform agencies from crisis-affected regions into the image of the northern partner, and basically is meant to create administratively and financially sound partners that can abide by required reporting mechanisms (Stephen 2017). Finally, the term capacity building misses out on the possibilities of mutuality or capacity sharing where different partners learn from each other's strengths.

In classic humanitarianism, the recipients of aidoften addressed as the beneficiaries, i.e. those to whom good is done-are typically depicted as victims. In everyday practice, however, they are often seen as potential cheats. The number of aid seekers usually surpasses resources, and agencies do all they can to control, check and double-check the authenticity of victims' claims (Kibreab 2004). Although aid in this tradition is motivated by the desire to relieve suffering and is based on the ethics of a shared humanity, in practice, it is really delivered on the basis of mistrust of the society in which it operates and the local providers of aid and the aid recipients must be kept under close surveillance.

\section{Resilience humanitarianism}

The classic paradigm of Dunantist humanitarianism has dominated conversations among humanitarians for decades, despite contesting discourses both from concerned scholars and from within the domain (such as do no harm; listening projects; Linking Relief to Rehabilitation and Development and rights-based approaches that gained popularity in the 1990s but were largely silenced when the 'war on terror' began). For some years, however, a different discourse has gained momentum, which is a discourse based on resilience. It corresponds to changes in aid that were enabled by technological innovations, such as the use of digital payment systems or drones, but I see an especially major turn in the stories that international actors tell about the nature of crises, crisis-affected populations and their societies and ultimately about aid itself.

The resilience paradigm rests on the notion that people, communities and societies (can) have the capacity to adapt to or spring back from tragic life events and disasters. Disaster, rather than being a total and immobilizing disruption, can become an event in which people seek continuity by using their resources to adapt. Classic humanitarianism, as elaborated above, used to be framed around the idea of a strict separation between crisis and normality. In the last decade, under the influence of resilience thinking, this dominant notion has begun to shift spectacularly, leading to an entirely different approach to aid. Resilience humanitarianism began in the realm of disaster relief, whereby the resilience of local people and communities and the importance of local response mechanisms became the core of the Hyogo Framework for Action in 2004. National players now take greater control of disaster response which is anchored on the recognition of the resilience of people and communities. International aid has increasingly retreated, mentally and physically, from these situations (unless they concern mega-disasters). This move towards resilience reflects changing insights and the growing national capacity for responding to disaster. It also recognizes that the international community foresees that it cannot continue to intervene in the rapidly growing number of disasters caused by climate change.

In the past few years, resilience humanitarianism has spilled over to conflict areas and refugees. New trends can usually be pinpointed to a hallmark crisis, as in the case of refugee care breaking through the binary between crisis and normality, exemplified by the Syria crisis, where $90 \%$ of the refugees in the region live outside the camps. ${ }^{6} \mathrm{Hu}-$ manitarian actors at the beginning of the Syrian crisis operated strictly on the basis of offering their assistance to people in camps but had to quickly adapt their services to this situation. The refugee camp as an icon of aid is giving way to a notion that refugees are resilient in finding ways to survive. A key tenet of the new way of thinking of resilience is that crisis response is much more effective and cost-efficient when it takes into account people's capacity to respond, adapt and bounce back, coined by the president of the Rockefeller Foundation as 'the resilience-dividend' (Rodin 2014).

Today's 'policy speak' builds on continuity between crisis and normality, and UN reports now often refer to 'crisis as the new normality'. In the latest annual report on food security, and referring to the protracted nature of displacement, the World Food Programme, for example, speaks of the 'new normal' of protracted crisis. Crisis as the new normality is also used when referring to areas where climate change and other factors have resulted in semi-permanent crises. It profoundly changes the core of how humanitarian aid is conceptualized. Rather than 
viewing humanitarianism as a separate form of intervention, the 2016 World Humanitarian Summit proclaimed the need to bridge humanitarian action to development and to peacebuilding and the resolution of crisis (Ban 2016). Similarly, the recent Global Compact on Refugees of June 2018 (final draft) ${ }^{7}$ can be seen as a game changer in the shift from classic to resilience humanitarianism, as it focuses on promoting the resilience of refugees as well as seeking negotiated solutions to refugee situations in the local context, rather than according undisputed status to refugee rights as laid down in the 1951 Convention.

One of the manifestations of this trend is the renewed appreciation of state control of humanitarian responses. This is partly related to the assertiveness of states, particularly in the many areas where humanitarian emergencies occur in states with strong regimes leaning towards authoritarianism. There is also a renewed respect for the role of the state in relation to the humanitarian endeavour. In the case of socio-natural disaster, the central role of the state has been laid down in the Hyogo Framework of 2005 and further strengthened in the Sendai Framework of 2015. Host governments of refugee flows likewise play more visible roles, and forms of hybrid governance evolve when governments and the UN Office of the High Commissioner for Refugees (UNHCR) develop a division of labour whereby the state is seen to provide the negative rights (enabling residence for example), while UNHCR secures positive rights (service provision) (Kagan 2011). This is closely related to the abandonment of the idea of camps as the default solution to refugee care, because the role of host governments comes more to the fore in case of refugees staying in host communities. In cases of open conflict, the role of the state-often directly engaged in the violent conflict-in humanitarian affairs continues to be highly problematic.

The perception of crisis-affected populations is also changing. This can be illustrated by the evolution of the language of humanitarian standards. The 1994 Code of Conduct was agency-centred: 'We shall...' (Hilhorst 2005). Consider, for example, article 7 that said: 'Ways shall be found to involve programme beneficiaries in the management of relief aid' (emphasis added). Today's replacement of the Code, the Core Humanitarian Standard, is centred on the crisis-affected community and reads as a list of what communities may rightfully expect, for example, 'Humanitarian response is based on communication, participation and feed-back' (article 4). ${ }^{8}$ The term 'beneficiary' seems to be backgrounded, if not buried, and replaced by terms like 'survivor,' 'first responder' or even 'client'. The International Federation of the Red Cross stated in its annual 2013 World Disaster Report: 'Disaster-affected people are not 'victims' but a significant force of first responders' (International Federation of the Red Cross (IFRC), 2013: 17). Considerable attention is given to the resilience of refugees, with literature and policy briefs converging in their portrayal of refugees as economic agents (Betts et al. 2014; Betts and Collier 2017). This leads to a form of 'resilience humanitarianism' that responsibilizes refugees to govern and enable their own survival (Ilcan and Rygiel 2015).

Resilience is not just a property of crisis-affected populations; it has also been associated with a form of governance of complexity as pointed out by Chandler (2014), namely a form of governance 'from below'. Resilience humanitarianism fits within this complexity of (neoliberal) forms of governance that decentralize the state's governance functions in favour of non-state or private actors. It also seeks to responsibilize crisis-affected populations-refugees and survivors of disaster-in particular. One consequence of this is that the responsibility of the state to protect its citizens gets increasingly blurred and backgrounded. In the words of Mark Duffield, resilience 'has called forth, allegedly for our own benefit, a historically novel, post-security condition. It is a condition where being unprepared is not so much an oversight or act of neglect, for many - especially the world's poor and marginalised - it is rapidly becoming an officially sanctioned way of life' (Duffield 2012). In particular, when refugees stay outside of camps, they increasingly become an indistinguishable part of the so-called precariat, the poorest of the poor, who have no linkages to the formal parts of society-not as wage workers, not as consumers and not as politically significant members of an electorate (Standing 2014). They survive by navigating their precarious conditions on a day-to-day basis. In a world in which an estimated one billion people-migrants and resident poor-are part of this precariat, refugees may become a hardly distinguishable lot of urban poor, and is equally left to fend for themselves. There is a real risk that the politics of resilience towards refugees turns instead to a politics of abandonment.

While the paradigm of resilience affects governance relations writ large, this article especially points out how the discourse has invaded the languages and practices of humanitarian assistance. As the boundaries between crisis and normality (partly) evaporate, the conceptualization of the humanitarian arena also changes. Whereas humanitarian actors and stakeholders used to refer to a humanitarian system (depicted as the machinery metaphor in the introduction of this article), now reference is increasingly made to a humanitarian ecosystem. The ecosystem is less international humanitarian agency-centred and recognizes a large range of service providers, including the private sector and a host of national and local responders (for an illustration see Betts and Bloom 2014: 9).

The question is, what does this new paradigm mean for the identity and legitimacy of humanitarian agencies, in particular the humanitarian INGOs and to a lesser extent the implementing branches of the UN? What, if any, is the role of the humanitarian principles when service delivery is recognized as a fragmented endeavour of a multitude of 
actors that are loosely connected in an ecosystem? What is the scope of humanitarian assistance? Where do its responsibilities start, and importantly, where do they end? What is the added value and future roles of international humanitarians? Breaking through the binary of crisis and normality and the upsurge of the discourse of resilience is eroding the very foundations of exceptionality on which humanitarian action used to be premised. No wonder then that humanitarian agencies are in disarray about how they can find a legitimate role for themselves in the future.

\section{How can two humanitarianisms operate alongside each other?}

The table below illustrates the radical difference between the two humanitarianisms that were discussed in the previous sections.

\begin{tabular}{|c|c|c|}
\hline & Classic humanitarianism & Resilience humanitarianism \\
\hline Keyword & Humanitarian system & Humanitarian ecosystem \\
\hline Scope & $\begin{array}{l}\text { Humanitarian space is the } \\
\text { operating environment for } \\
\text { humanitarian action in } \\
\text { which humanitarians work } \\
\text { according to the principles } \\
\text { of neutrality, impartiality } \\
\text { and humanity }\end{array}$ & $\begin{array}{l}\text { Interventions as open } \\
\text { space in which different } \\
\text { actors operate }\end{array}$ \\
\hline $\begin{array}{l}\text { Humanitarian } \\
\text { crisis }\end{array}$ & $\begin{array}{l}\text { State of exception, } \\
\text { separated from normality }\end{array}$ & $\begin{array}{l}\text { Crisis as the new normality } \\
\text { Refugee camp is a relic of } \\
\text { modernity }\end{array}$ \\
\hline $\begin{array}{l}\text { Humanitarian } \\
\text { needs }\end{array}$ & $\begin{array}{l}\text { Needs are triggered by } \\
\text { the crisis }\end{array}$ & $\begin{array}{l}\text { Needs are offset against } \\
\text { capacities and resilience }\end{array}$ \\
\hline $\begin{array}{l}\text { Who provides } \\
\text { aid? }\end{array}$ & $\begin{array}{l}\text { International humanitarian } \\
\text { agencies central in } \\
\text { determining aid }\end{array}$ & $\begin{array}{l}\text { Renewed attention to } \\
\text { national and local } \\
\text { authorities as responsible } \\
\text { service providers } \\
\text { More systematic attention } \\
\text { to 'other' providers such } \\
\text { as private sector, new } \\
\text { humanitarians, local services }\end{array}$ \\
\hline $\begin{array}{l}\text { Humanitarian } \\
\text { action }\end{array}$ & $\begin{array}{l}\text { Projects defined } \\
\text { according to } \\
\text { humanitarian principles }\end{array}$ & $\begin{array}{l}\text { Aid primarily facilitates } \\
\text { resilience building, } \\
\text { engagement with } \\
\text { advocacy to aid } \\
\text { communities seeking } \\
\text { services }\end{array}$ \\
\hline $\begin{array}{l}\text { International } \\
\text { humanitarians }\end{array}$ & $\begin{array}{l}\text { Driven by their principles, } \\
\text { although evaluations } \\
\text { observe they deviate in } \\
\text { practice }\end{array}$ & $\begin{array}{l}\text { Seeking to apply principles } \\
\text { in contextual way } \\
\text { Seeking bridges with } \\
\text { development and } \\
\text { peacebuilding }\end{array}$ \\
\hline $\begin{array}{l}\text { Local } \\
\text { institutions }\end{array}$ & $\begin{array}{l}\text { Either spoilers and causes } \\
\text { of crises or in need of } \\
\text { capacity building by } \\
\text { international community. }\end{array}$ & $\begin{array}{l}\text { Foregrounded in localization } \\
\text { rhetoric, practice continued } \\
\text { emphasis on need for } \\
\text { capacity building }\end{array}$ \\
\hline Aid recipients & Victims or cheats & $\begin{array}{l}\text { Survivors and first responders } \\
\text { Active and resilient }\end{array}$ \\
\hline
\end{tabular}

The question is how do these two paradigms relate to the realities in humanitarian action? While the paradigms are partly consecutive, they are also used in parallel. Resilience humanitarianism challenges the dominant role of classic humanitarianism, but the latter has far from disappeared. To some extent, the paradigms may be seen to apply to different conditions of crises. Dunantist approaches are especially visible in high-intensity conflict scenarios, whereas resilience approaches increasingly take over humanitarianism in refugee care, fragile settings and disasters triggered by natural hazards. To a large extent, however, the paradigms can be seen to reflect two faces of the same realities: highlighting different properties of reality and backgrounding others. To elaborate on the point how the paradigms focus on different properties of crisis-affected areas, let me revisit the issues of the nature of crisis, the role of local actors and affected communities and the role of international agencies.

\section{Crises as continuity and discontinuity}

Crisis in classic humanitarianism is seen as a societal state that is totally different from peace, and disasters as radical disruptions of development. This is the twin logic that constructs crisis as a temporary and total disruption of society and reconstruction as restoring the normality of a neoliberal modern state that democratically interacts with other constituent powers in society (Calhoun 2010). Resilience humanitarianism seems to flip the image and focus on the continuity of institutions and capacities during crisis.

It only takes a cursory look at the wide literature on crisis and conflict to see that conflicts and disasters are breakpoints of social order, with a considerable degree of chaos and disruption, but they are also marked by processes of continuity and reordering, or the creation of new institutions and linkages. This means that it is difficult to place boundaries around a crisis situation. Conflict and peace are sometimes clear-cut situations, but more often they are labels that are socially constructed. Violent conflict has an enormous and traumatizing impact on people and societies, and people know the difference between war and peace very well. They resent researchers who sanitize their situation and euphemistically speak of conflict, food insecurity and gender-based violence when they really mean war, hunger and rape. But acknowledging the suffering of war does not make the distinction between war and peace easier to draw. Conflict does not operate according to a single logic, and its drivers, interests and practices are redefined by actors creating their own localized and largely unintended conflict dynamics of varying intensity (Kalyvas 2006). Crises are the outcome of conditions that build up over long periods of time, and the transition to normality is also often marked by long periods of 
'no war no peace' situations (Richards 2005). Violence and predatory behaviour may continue long after war is formally over (Keen 2001).

The tendency of aid and international relations more generally to seek boundaries between normality and exceptionalism has partly been challenged by the resilience paradigm. However, resilience humanitarianism as elaborated above seems to exaggerate the continuity of capacity and to forget the importance of exceptionalism to alert political actors and the international community to take responsibility to protect and garner the resources required to provide protection. It may also undermine the importance of rights, as laid down in international law, accorded to refugees and crisis-affected populations. Nowhere is this clearer than in debates around international migration, where increasingly the special status of refugees gets buried in a generalized debate on (non-)rights of people engaged in mixed forms of migration. This may lead to a situation where refugees are deprived of the basic protection that is the core of the humanitarian mandate.

\section{Institutions as changing and multifaceted}

Conflict theory has for a long time assumed that local institutions and economies are either destroyed or subsumed in the logic of violence and war. This idea that institutions cease to exist during conflict led to a notion that reconstruction could start with a tabula rasa (Cramer 2006), and very much informed classic humanitarianism, that tended to by-pass local institutions in the provision of services. Resilience humanitarianism conversely seems to turn a blind eye to changes brought about by crisis and assumes that institutions can be relied on to play their roles as envisaged in neoliberal governance models.

Current insights reveal that (protracted) conflict situations are often characterized by multiple normative systems and hybrid institutions. State-endorsed institutions in these situations of institutional multiplicity (Di John 2008) figure in a complex and fragmented landscape inhabited also by traditional institutions, citizen arrangements, armed groups and political movements contesting the state. During crisis situations, institutions may become more in flux or disarray. Many of these institutions are multifaceted, and their contributions to conflict and to peace are often entangled.

The entangled, multifaceted nature of institutions is also obvious in the economy. In economies of war, the production, mobilization and allocation of resources are known to be organized to profit from and sustain the violence. However, there is a flip-side of this in the continuation of the normality of economies of production, transactions and distributions that we may call the economies of survival during crises. People hold on to normality as much as they can and continue planting their fields and trading their products. War and survival economies are deeply intertwined, and most activities are multifaceted, creating new forms of economic life (Nordstrom 2004). In the study of everyday practice, it becomes apparent how the logics of violence, survival and reconciliation are renegotiated in their local contexts and how they work upon each other. This means that approaches aiming to strengthen the economy of survival during crisis always risk harm in inadvertently supporting the economy of war at the same time.

In general terms, it can be stated that classic humanitarianism would focus on the linkages between the economy and the conflict-seeking to deliver aid without reinforcing these institutions. Resilience humanitarianism tends to build on the survival economy and people's resilience, but may be blind to the economic logics of the conflict, and risks of exploitation and abuse of people's vulnerability.

What both paradigms have in common is that aid agencies have the tendency to place themselves outside of the complex institutional realities in the area of intervention. In reality, international aid organizations and their interventions may be better considered as part of the local institutional landscape. They do not operate outside of societies but are embedded in local realities. They 'exist in an arena of social actors with competing interests and strategies' (Bakewell 2000: 104). Aid interlocks with social, economic and political processes in society, co-shaping local institutions and institutional transformation processes by working through, competing with or reinforcing them (Serrano 2012). Humanitarian emergencies are often dense with aid, and agencies may become a powerful factor in the reshaping of institutions, in intended and unintended ways.

It is therefore important to view how aid in its many variations co-shapes the institutional landscape in which aid is delivered. Moreover, it is important to view aid provision as relational action.

\section{Aid provision as relational action}

Notwithstanding their differences, in the final analysis, classical humanitarianism and resilience humanitarianism both centre on the act of giving, whereby the aid provider makes aid available to its recipients.

The lifeworlds and logics of aid providers and aid recipients have been subject to scholarly attention. With regard to aid providers, Raymond Apthorpe refers to Aidland, which has become the subject of a substantial strand of literature. 'Aidland is the trail (to use a word that usefully is both verb and noun, and about both process and place) of where foreign aid comes from, where it goes, and what then' (2005: 1). Aidland literature focuses on the lifeworld of 'development workers', which is seen as a self-referencing 'bubble'-very recognizable to people who have travelled in or were part of this 'Aidland'. 
Elizabeth Harrison, however, noted that this literature risks '[diverting] attention from the significance of both the politics and the material effects of development intervention while reinforcing a dichotomous picture of the relationship between "developers" and "recipients" (Harrison 2013: 246).

The lifeworlds of aid recipients have likewise been studied extensively. Since Barbara Harrell-Bond wrote about a dependency syndrome in 1986, the literature of aid recipients has alternated between contributions stressing the passive attitude of aid recipients and contributions focusing on the agency and capacities of crisis-affected people (Anderson and Woodrow 1993; Kibreab 1993). A key issue in this literature concerns the power relations and the 'making of the subject of aid' by labelling practices of aid agencies (Wood 1985; Moncrieffe and Eyben 2007). Categorizing people is a key aspect of humanitarian aid, as programmes have to make constant decisions about inclusion and exclusion and eligibility and non-eligibility of services. While categorizing may be an inevitable part of humanitarian aid, labelling goes further and its effects can be tremendous. It defines the identity of the labelling object as much as the identity of the labelling subject.

In the study of the working of aid paradigms, it is important to highlight the relational property of service provision. It is useful to make a small detour here to discuss the different politics at play in humanitarian aid. Humanitarian politics concern diplomacy and advocacy to convince parties to respect international humanitarian law and to grant humanitarian actors unrestricted access to people in need. Humanitarian aid is also subject to geopolitics and the politics of parties that instrumentalize aid to advance their interests. In addition, there are organizational politics that rule the hierarchies and power games within organizations and make organizations devise strategies in order to gain or retain their competitive advantage vis-à-vis other players.

As part of their organizational politics, NGOs are deeply involved in politics of legitimation (Hilhorst 2003, 2007). In my previous work on Philippine development NGOs, I defined the identity of an NGO as a claim-bearing label. With the self-identification as NGO (instead of civil society organization, public, private or other actor), an organization claims that it is value-driven and is 'doing good for the development of others' (Hilhorst 2003, p. 7). Finding legitimation as an NGO is a complex endeavour that involves the successful delivery of four sequential key messages. The first message is that there is an emergency that requires urgent action. The second is that the affected communities cannot cope with the emergency by themselves. The third is that the NGO has the required capability to deal with the crisis for the sake of the immediately affected. The fourth is that the NGO has no self-interest in this endeavour. Bringing across these four messages is a hallmark of much NGO action and constitutes the legitimation politics of the organization. The long-term habit of representing local actors as passive victims, incapable of dealing with crisis, should therefore not be understood as a misconception but could be seen as a crucial part of legitimation politics (conveying message two). In making the subject of aid, agencies create their own identity as rescuing force.

The classical core dyad of the aid arena-service providers and recipients-can therefore be seen as a tactical convolution where both parties are equally interested in representing the recipients as needy. On one side of the relation, crisis-affected people use their tactical agency to navigate their environment and figure out what makes them eligible for receiving aid. Mats Utas coined the term 'victimcy as a form of self-representation [...including...] self-staging as victim of war' (Utas 2005: 408). On the other side of the relationship, aid providers have a similar interest in foregrounding the victimized properties of the people they work for, for example, to convince their headquarters about the urgent needs of a project, lure the public at large into making donations and maintain their reputation as legitimate, disinterested service providers. While this has been interpreted as a form of cognitive dissonance (Marriage 2006b), I prefer to label this as tactical agency whereby agencies against their better judgement foreground the dependency of their beneficiaries, the people to whom they do good. The victimcy of aid seekers is thus coupled to what may be called the ignorancy of aid providers (Hilhorst 2016), creating a legitimate and comforting image of guardian angels coming to the rescue of people in distress.

The upsurge of resilience humanitarianism can be seen to challenge the core of humanitarianism: giving. For a long time, 'victimcy' and 'ignorancy' went hand in hand to maintain the comforting notion of aid providers meeting the needs of victimized populations. Will the changing language that steps away from victims to notions of responsibility and first responders erode the essential core of humanitarianism, or will aid agencies find new ways to revive the relation between providers and recipients of aid?

\section{Conclusion}

This article analysed two radically different paradigms of aid: classic humanitarianism and resilience humanitarianism. The strict exceptionalism of classical humanitarianism has given way to a breakthrough of the binary between exception and normality in resilience humanitarianism. In this paradigm, humanitarian agencies are no longer the sole centre of the humanitarian universe, and conceptions of local institutions and crisis-affected populations have flipped from invisibility to visibility 
and from depreciation to appreciation. It may be obvious that both paradigms rarely occur in such an unadulterated form as they have been described in this article, but tearing them apart for the analysis provides, it is hoped, fresh input into discussions on humanitarian assistance.

Paradigms of aid can be seen to provide a logic to aid that recombines selective understandings of reality in more or less coherent stories that aid tells about itself. The article has studied this from an arena perspective that views humanitarianism as an arena in which actors socially negotiate policies and practices of aid. When we first developed this perspective, we used it to analyse the everyday politics of aid and to interrogate the classical paradigm of principled humanitarian action (Hilhorst and Jansen 2010; Hilhorst and Serrano 2010). In the meantime, this dominant paradigm has been paralleled with and partly overtaken by a resilience paradigm. In this article, then, I have interrogated both the classical paradigm and the resilience paradigm of humanitarianism.

At first sight, the resilience paradigm seems more compatible with the social realities of crisis. Its focus on the continuum between crisis and normality, and its portrayal of the humanitarian system as an ecosystem, for example, better correspond with notions developed in social theory on crises and crisis response than its rival, classical paradigm. However, on closer scrutiny, the resilience paradigm is as much based on selective understandings, foregrounding particular properties of social realities, while ignoring others. Equally, it consists of a set of ill-tested assumptions that seem to reduce the multiplicity of social reality to a singular discourse.

There are multiple realities in crises, institutions and aid relations, and actors use their paradigms to selectively understand these realities. Crises are marked by continuity and discontinuity, and aid needs to grapple with these multiple faces of crises. Instead, classical and resilience paradigms have the tendency to overly focus on one of the faces of crises: classical humanitarianism focuses on the discontinuities, disruption and the need for outside assistance, whereas resilience humanitarianism seeks continuity in rendering affected populations primarily responsible for their own survival.

When we look at the everyday politics of aid, as it evolves in practice, classical and resilience humanitarianism both have the tendency to underestimate the relational and negotiated nature of aid. Importantly, they fail to see the humanitarian's own role in shaping the realities in which they operate. By elaborating the interrelated concepts of 'victimcy' and 'ignorancy', the article showed how representations of victims as passive recipients of aid is an essential part of the aid game and a display of tactical agency on the sides of recipients and aid providers to ensure the perpetuation of the aid relation. A major question is how the aid game will evolve in resilience humanitarianism that walks a thin line between support and abandonment, between enabling the self-reliance of crisis-affected populations and refugees, and depriving them of basic protection.

This paper, in short, invites scholars and reflective practitioners to take an open look at the discourses and practices of aid. How is power enacted? How do actors respond to the multifaceted nature of institutions? Where are the cognitive dissonances between new ideas of humanitarians and old habits that may not disappear? How do crisis-affected populations interpret this information and strategize to seek the services they require? How do aid agencies affect the realities in which they operate?

\section{Endnotes}

${ }^{1}$ International Federation of the Red Cross and Red Crescent Societies.

${ }^{2}$ The Advanced Learning Network for Accountable Practice (ALNAP). Available at www.alnap.org.

${ }^{3}$ See www.sphere.org.

${ }^{4}$ The (former) Humanitarian Accountability Programme (HAP).

${ }^{5}$ See www.chsalliance.org.

${ }^{6} \mathrm{See}$ http://data.unhcr.org/syrianrefugees/regional.php; http://ec.europa.eu/echo/files/aid/countries/factsheets/ turkey_syrian_crisis_en.pdf.

${ }^{7}$ See https://reliefweb.int/report/world/global-compactrefugees-final-draft-26-june-2018

${ }^{8}$ See www.chsalliance.org.

\section{Acknowledgements}

This paper was made possible by a $\mathrm{VICl}$ grant of the Netherlands Organisation for Scientific Research NWO, grant number 453-14-013. It is the revised version of Hilhorst, D. (2018) 'Arenas'. In T. Allen, A. MacDonald, H. Radice. Humanitarianism: A Dictionary of Concepts. Routledge, London, pp. 30-51. This was done with the approval of both publishing houses: Springer and Routlegde. I am very grateful for this opportunity to make the (revised) paper accessible for open access.

\section{Funding}

This paper was made possible by a VICI grant from the Netherlands Organisation for Scientific Research NWO, grant number 453-14-013.

\section{Availability of data and materials}

The article is based on secondary sources that are all referenced in the bibliography.

\section{Author's contributions}

This is a single-authored paper. The author read and approved the final manuscript.

\section{Competing interests}

The author declares that she has no competing interests.

\section{Publisher's Note}

Springer Nature remains neutral with regard to jurisdictional claims in published maps and institutional affiliations. 
Received: 9 April 2018 Accepted: 10 August 2018

\section{Published online: 10 September 2018}

\section{References}

Anderson M, Woodrow P (1993) Reducing vulnerability to drought and famine. In: Field JO (ed) The Challenge of Famine, Recent Experience, Lessons Learned. Kumarian Press, West Hartford

Apthorpe R (2005) Postcards from Aidland, or love from bubbleland. Paper presented at a graduate seminar at IDS, University of Sussex 10 June

Artur L (2011) Continuities in crisis. Everyday practices of disaster response and climate change adaptation in Mozambique. PhD Thesis, University of Wageningen Available at http://edepot.wur.nl/166246.

Artur L, Hilhorst D (2012) Everyday realities of climate change adaptation in Mozambique. Glob Environ Chang 22:529-536

Auteserre S (2014) Peaceland: conflict resolution and the everyday politics of international intervention. Cambridge University Press, New York

Bakewell O (2000) Uncovering local perspectives on humanitarian assistance and its outcomes. Disasters 24:103-116

Ban Ki-moon. 2016. One humanity: shared responsibility. Report of the SecretaryGeneral for the World Humanitarian Summit. UN general assembly, 2 February. Available at www.agendaforhumanity.org/sites/default/files/\%5BA70-709\%5D\%20Secretary-General\%27s\%20Report\%20for\%20WHS.pdf

Betts, Alexander and Louise Bloom. 2014. Humanitarian innovation. The state of the art. Occasional Policy Paper 009, OCHA Policy and Studies Series. Available at www.unocha.org/sites/dms/Documents/OP9_Understanding\%20Innovation_ web.pdf

Betts A, Bloom L, Kaplan J, Omata N (2014) Refugee economies: rethinking popular assumptions. Humanitarian Innovation Project, University of Oxford Oxford Available at www.rsc.ox.ac.uk/files/files-1/refugee-economies-2014.pdf

Betts A, Collier P (2017) Refuge: Transforming a Broken Refugee System. Penguin, London

Blaikie P, Cannon T, Davis I, Wisner B (1994) At risk: natural hazards, people's vulnerability and disasters. Routledge, London

Bob C (2005) The marketing of rebellion: insurgents, media and international activism. Cambridge University Press, New York

Calhoun C (2010) The idea of emergency: humanitarian action and global (dis) order. In: Fasin D, Pandolfi M (eds) Contemporary states of emergency. Zone Books, New York

Chandler D (2014) Beyond neoliberalism: resilience, the new art of governing complexity. Resilience 2(1):47-63. https://doi.org/10.1080/21693293.2013.878544

Colebatch, H. K. 2002. Policy: concepts from the social sciences. 2nd edn. Buckingham: Open University Press

Cramer C (2006) Civil war is not a stupid thing: accounting for violence in developing countries. Hurst \& Co., London

DeChaine R (2002) Humanitarian space and the social imagery: Médecins Sans Frontières/Doctors without borders and the rhetoric of global community. Commun Inq 26(4):354-369

Di John J (2008) Conceptualising the causes and consequences of failed states: a critical review of the literature. In: Working paper. Crisis States Research Centre, London

Donini A (2012) The golden fleece: manipulation and independence in humanitarian action. Kumarian Press/Lynne Rienner Publishers, Boulder, CO and London

Duffield M (2010) Risk-management and the fortified aid compound: everyday life in post-interventionary society. Journal of Intervention and State Building 4(4):453-474

Duffield M (2012) How did we become unprepared? Emergency and resilience in an uncertain world. In: Panel Discussion at the British Academy. 7 November Available at www.britac.ac.uk/events/2012/

Fernando U, Hilhorst D (2006) Everyday practices of humanitarian aid: tsunami response in Sri Lanka. Dev Pract 16(3 and 4):292-302

Gordon S, Donini A (2015) Romancing principles and human rights: are humanitarian principles salvageable? International Review of the Red Cross 97(897/898):77-109. Principles guiding humanitarian action. https://doi.org/ $10.1017 / 51816383115000727$

Harrell-Bond B (1986) Imposing aid: emergency assistance to refugees. Oxford University Press, Oxford

Harrison E (2013) Beyond the looking glass: Aidland reconsidered. Crit Anthropol 33(3):263-279

Harvey P (2009) Towards good humanitarian government: the role of the affected state in disaster response. In: HPG report 29. Overseas Development
Institute, London Available at www.odi.org/sites/odi.org.uk/files/odi-assets/ publications-opinion-files/5076.pdf

Hilhorst D (2003) The real world of NGOs: discourse, diversity and development. Zedbooks/Manila: Ateneo de Manila University Press (Philippine edn in English), London

Hilhorst D (2004) Complexity and diversity: unlocking domains of disaster response. In: Bankoff G, Frerks G, Hilhorst D (eds) Mapping vulnerability: disaster, development and people. Earthscan, London

Hilhorst D (2005) Dead letter or living document? Ten years code of conduct for disaster relief. Disasters 29(4):351-369

Hilhorst D (2007) The art of NGO-ing. Everyday practices as key to understanding development NGOs. In: Opoku-mensah P, Lewis D, Tvedt T (eds) Reconceptualising NGOs and their roles in development. Aalborg University Press, Aalborg

Hilhorst, Dorothea. 2016. 'Aid-society relations in humanitarian crises and recovery'. Inaugural Lecture, International Institute of Social Studies, Erasmus University Rotterdam

Hilhorst D, Douma N (2018) Beyond the hype? The response to sexual violence in the Democratic Republic of the Congo in 2011 and 2014. Disasters 42S: 79-98

Hilhorst D, Jansen B (2010) Humanitarian space as arena: a perspective of everyday practice. Dev Chang 41(6):1117-1139

Hilhorst D, Schmiemann N (2002) Humanitarian principles and organizational culture: everyday practice in Médicins Sans Frontières-Holland. Dev Pract 12(3/4):490-500

Hilhorst D, Serrano M (2010) The humanitarian arena in Angola 1975-2008. Disasters 34(s2):183-201

Hilhorst D, van Leeuwen M (2005) Grounding local peace organizations. A case study of southern Sudan. J Mod Afr Stud 43(4):537-563

Hyndman J (2012) Dual disasters: humanitarian aid after the 2004 tsunami. Kumarian Press, Sterling

Ilcan S, Rygiel K (2015) Resiliency humanitarianism': responsibilizing refugees through humanitarian emergency governance in the camp. Int Political Sociol 9(4):333-351

International Federation of the Red Cross (IFRC) (2013) World Disaster Report 2013. In: Focus on technology and the future of humanitarian action. International Federation of the Red Cross and Red Crescent Societies, Geneva

Jansen B (2011) The accidental city: violence, economy and humanitarianism in Kakuma refugee camp, Kenya. PhD Thesis, Wageningen University

Kagan, Michael. 2011. 'We live in a country of UNHCR'. The UN surrogate state and refugee policy in the Middle East. New Issues in Refugee Research, Research Paper no. 201. Geneva, UNHCR, Policy Development and Evaluation Service

Kalyvas S (2006) The logic of violence in civil war. Cambridge University Press, Cambridge

Keen D (2001) War and peace: what's the difference? Int Peacekeeping 7(4):1-22

Kibreab G (1993) The myth of dependency among camp refugees in Somalia 1979-1989. J Refug Stud 6(4):321-349

Kibreab G (2004) Pulling the wool over the eyes of the strangers: refugee deceit and trickery in institutionalized settings. J Refug Stud 17(1):1-26

Kyamusugulwa P (2014) Community-driven reconstruction in the Eastern Democratic Republic of the Congo: capacity building, accountability, power, labour, and ownership. Wageningen Univeresity: PhD Thesis

Kyamusugulwa P, Hilhorst D (2015) Power holders and social dynamics of participatory development and reconstruction: cases from the Democratic Republic of Congo. World Dev 70:249-259

Leader N (2002) The politics of principle: the principles of humanitarian action in practice. Humanitarian Practice Network, London

Leeuwen V, Mathijs (2009) Partners in peace: discourses and practices of civil society peacebuilding. Ashgate Publishing, Aldershot

Macdonald I (2017) Humanitarian action and terrorism: perceptions from the Muslim world. Harmattan, Paris

Marriage Z (2006a) Not breaking the rules, not playing the game: international assistance to countries at war. Hurst \& Co., London

Marriage Z (2006b) The comfort of denial: external assistance in southern Sudan. Dev Chang 37(3):479-500

Maxwell D, Majid N (2016) Famine in Somalia. In: Competing imperatives, collective failures, 2011-12. Hurst Publishers, London

Minear $L$ (1999) The theory and practice of neutrality: some thoughts on the tensions. In: Humanitarianism and war project. International Committee of the Red Cross, Geneva 
Moncrieffe J, Eyben R (eds) (2007) The power of labelling: how people are categorized and why it matters. Earthscan, London

Mosse D (2005) Cultivating development: an ethnography of aid policy and practice. Pluto Press, London

Nordstrom, Carolyn. 2004. Shadows of war. Violence, power and international profiteering in the twenty-first century. Berkeley, CA: California University Press

Olson RS (2000) Toward a politics of disaster: losses, values, agendas, end blame. Int J Mass Emerg Disasters 18(2):265-288

Richards P (1996) Fighting for the rain forest: war, youth and resources in Sierra Leone, Porthsmouth. Heinemann

Richards P (2005) New war. An ethnographic approach. In: No peace no war: an anthropology of contemporary armed conflicts. James Currey, Oxford

Rodin J (2014) The resilience dividend: managing disruption, avoiding disaster, and growing stronger in an unpredictable world. Profile Books, London

Serrano M (2012) Strengthening institutions or institutionalising weaknesses? Interactions between aid and local institutions in Huíla Province, Angola. Wageningen University, PhD Thesis Available at http://edepot.wur.nl/193127

Standing G (2014) A precariat charter: from denizens to citizens. Bloomsbury Academic, London

Stephen M (2017) Partnerships in conflict: how violent conflict impacts local civil society and how international partners respond. International Alert, Oxfam https://policy-practice.oxfam.org.uk/publications/partnerships-in-conflict-howviolent-conflict-impacts-local-civil-society-and-h-620359

Stoddard A (2003) Humanitarian NGOs: challenges and trends. In: Macrae J,

Harmer A (eds) Humanitarian action and the 'Global War on terror': a review of trends and issues HPG report 14. www.odi.org.uk/hpg/papers/ hpgreport14.pdf.

Utas M (2005) Victimcy, girlfriending, soldiering: tactic agency in a young woman's social navigation of the Liberian war zone. Anthropol Q 78(2):403-430

Wood G (1985) The politics of development policy labelling. Dev Chang 16:347-373

\section{Submit your manuscript to a SpringerOpen ${ }^{\circ}$ journal and benefit from:}

- Convenient online submission

- Rigorous peer review

- Open access: articles freely available online

- High visibility within the field

- Retaining the copyright to your article

Submit your next manuscript at $\boldsymbol{\nabla}$ springeropen.com 